\title{
Industrial Accident and Safety Hazards at the Workplace: A Spatio-Physical Workplace Approach
}

\author{
Oyesola Animashaun
}

\author{
Kola O. Odeku \\ Faculty of Management and Law, University of Limpopo, Turfloop, South Africa
}

\section{Doi:10.5901/mjss.2014.v5n20p2949}

\begin{abstract}
The challenge facing management from time immemorial is that of creating a work environment that not only attracts, keeps and motivates its workforce, but also organizes the workplace in such a way as to ensure the safety and health of the workforce. The organization of the workplace should also provide proactive ways of evacuating the workforce and preventing neighbours from being injured in cases of workplace accidents and hazardous disasters. Focusing on the situation in Nigeria, this treatise examines the interrelationship between health and safety and the layout of the physical work environment. Although, there is dearth of material on this area, researchers have established that good physical layout of the workplace coupled with efficient management processes prevents unnecessary accidents at the workplace and boost productivity and improves organizational performance.
\end{abstract}

Keywords: Health and Safety, Office Lay-out, Physical Work environment, Accident and Hazard, Occupational Safety.

\section{Introduction}

The well-publicized and evidenced-based impact of physical arrangement of the workplace in an organisation business performance is very important to the stake holders and also the workers who perform different duties in the organisatin. (Price, 2002). In most cases, the impact of the physical environment on health and safety in the workplace is almost nonexistent (Fisher, 2003). Against the above backdrop, in recent years, the issues surrounding health and safety are becoming more prominent and new phrases, ideas and concepts are being introduced (Freeman, 2010). The occurrence of the Chernobyl Radioactive Accident, for instance led to the introduction of concepts such as Safety climate, safety culture and the likes (Choudhry et al. 2007). The occurrence of industrial accidents, apart from causing fatalities and disabilities (Courtney et al. 2001), is costly to the employer in term of the bad publicity, litigation costs, and damages payable to the victims and/or their survivors and the punitive damages usually imposed by the government, regulators and other stakeholders (Stefan, 2006). It also creates the problem of decreased productivity, difficulty of replacement and training of new hands (Oluwole, 1991). Such industrial accidents and the quest to provide harmonious industrial relations and ensure the safety of the populace has made many countries to enact or update their safety and health laws ( Mensah and Julien, 2011). This has affected the way in which the workplace is arranged. Apart from the health and safety concern, it has been discovered that the only way by which organizations could stay ahead of competition is to continually re-invent itself using the workplace as a tool to meet these goals (Rothwell et al. 2009).

The United States, for instance, enacted the Occupational Safety and Health Act (1970). It also made provision for Occupational Safety and Health Administration (OSHA) which develops and enforces health and safety standards. The Occupational Safety and Health Review Commission (OSHRC) created under the same Act, is an independent Federal agency, created to decide contests of citations or penalties resulting from OSHA inspections of American workplaces. The National Institute for Occupational Safety and Health, conduct health and safety research to suggest new standards and update previous ones. In South Australia, there are Occupational Health Safety and Welfare Act (1986); New South Wales (Australia), Occupation Health and Safety (OHS) Act 2000, Coal Mines Regulations Act 1982, Dangerous Goods Act 1975, Mines Inspection Act 1901, Rural Workers Accommodation Act 1969, Safety Rehabilitation and Compensation (1988), Safety Guideline Notes(1988), Occupation Health and Safety (OHS) regulations(2001). The Federal Republic of Nigeria however, has no comprehensive health and safety legislation, (Coker et al. 2009) apart from the Factories Act Cap F1, Laws of the Federation (2004). This Factories Act 1955 was essentially a copious reproduction of the English Factories Act (1938). The English Act has been updated, amended and reviewed several times, but the Nigerian variant 
has not undergone any major amendment. The Nigerian Factories Act Cap F1 is supplemented by few regulations, particularly Dock (Safety of Labour) Regulations, Factories (Wood making Machinery) Regulations and Factories (Notification of Dangerous Occurrences) Regulations. It is noteworthy to state that these are at best rudimentary and deal only with factories, to the exclusion of the other workplaces. Furthermore, the Act was restricted in its application to persons employed to do manual labour (Oluwole, 1991). The new Employee Compensation Act (2010) was promulgated to replace the repealed Workmen Compensation Act, Cap W7, Laws of the Federation (2004). This Act made provision for payment of compensation to employees who are injured in the course of their employment or their dependants in cases of death.

Health, as defined by Longman's Dictionary of Contemporary English, is a state of being well in body and mind and free from disease. It is also defined as the protection of the body and mind of people from illness resulting from materials, processes or procedures used in the workplace (Hughes and Ferrett, 2005). Safety is described by the same dictionary as a condition of being free from danger, harm or risk, while Hughes and Ferrett (2005) defined it as protection of people from physical injury. They stated further that "the borderline between health and safety is ill defined as the two words are used together to indicate concern for the physical and mental well-being of individual at the workplace." Accident on the other hand is defined as any unplanned event that result in the injury or ill health of people or damages or loss to property, plant, materials or environment or loss of business opportunities (Hughes and Ferrett, 2011). It was defined in the case of Fenton v Thoerley \& Co. Ltd. Appeal Case, (1903), as an unforeseen happening, an unexpected occurrence which produces hard loss. Section 73 of The Employee Compensation Act defines Accident as an occurrence arising out of, or in the course of work which results in fatal or non-fatal occupational injury that may lead to compensation in terms of section 73. Hazard is the potential of a substance, activity or process to cause harm ( Rogers, 2003). According to Hughes and Ferrett (2005) on Recognising and controlling workplace hazards, National Council of Occupational health and safety Guidelines, a job hazard is anything that can cause physical and mental injury at the workplace. The Guideline distinguishes between health and safety hazard. It states that safety hazard cause immediate injury, direct injury or trauma such as severed finger, crushed hand, broken nose and eye damage; while health hazard cause immediate illness (acute) or over a long period (chronic). It listed the followings as safety hazard: unguarded machinery, damaged plugs, outlets and wires, unbalanced walking surface, tripling hazard, falling objects, holes in the ceiling, blind spots (vehicles). Health hazards are Chemicals (dusts, gases, vapours) which causes fire, burns, and explosions or affects the vital organs. Biological: (animals, insects, bacteria, and virus/blood) which may result in HIV, flu, hepatitis, tuberculosis, and rabies and so on. Physical hazards are noise, radiation, heat, cold, stress, repetitive motion which causes, deafness, burns, blood disorder, cancer, musculo- skeletal injury and heat stroke(hypothermia) Risk, is the likelihood of a substance, activity or process to cause harm. This can be reduced if hazards are controlled by good physical layout and conscientious management (Hughes and Ferrett, 2005).

\section{Physical Work Environment}

The physical work environment consists of those elements in the workplace which directly impact the human senses and the physical or mental safety and well-being of an employee (Mark et al. 2004). Many hazards in the physical surroundings pose an immediate threat of bodily or emotional injury while other environmental conditions influence worker health more gradually over time (People, 2011). These are traditionally the purview of occupational health and safety or health policy and legislation, yet it also includes broader conditions such as workplace opportunities to improve or maintain fitness levels, try new leisure activities or develop meaningful social connection (Lundgren and McMakin, 2013).

According to Alberta Health Services (AHS, 2009), key categories and examples of workplace health, safety and wellness issues in the physical environment include but not limited to: (AHC, 2009).

"a. chemical: solvents; tobacco smoke b. mechanical: machine hazards; usage of tools

c. biological: communicable diseases; poor hygiene practices

d. transportation: inclement weather; poor vehicle maintenance

e. physical: noise; heat f. energy: electrical

g. ergonomic: heavy lifting; repetitive action

h. built environment: access to safe exercise and leisure opportunities; outdoor eating areas

i. technology: unsafe use of mobile equipment and technologies

j. fitness, leisure, social: social eating areas; fitness classes; group events."

The physical work environment is important to the health and safety need of any workplace (Carayon et al. 2006). 
Proper arrangement of the workplace enhances the safety and the health condition of the staff and aids evacuation in the case of disaster (Henderson and Tunks, 2013). For instance, the manner of arrangement of the workplace, and the lack of adequate infrastructure could make workers contact communicable diseases such as tuberculosis, flu and so on. (Mehtar,2010.).

\section{Modern Workspace}

According to Vischer et al. (2008), "evidence from commercial leasing agents, office furniture manufacturers, the design professions and building contractors indicates that some new knowledge is finding its way into the real estate industry as commercial building owners and tenants demand better quality workspaces for their employees." Until recently, the design of office buildings adhered to a 19th Century model of work (Duffy, 1997). Workers were asked to perform rather than to think, brought together in space and time so that they can be supervised, have access to necessary tools, and have a clear barrier between work and their other activities. These workers occupy standardized and often uniform workspace (Orna, 2005). Contemporary workspace is more likely to be in the form of offices, and reducing occupancy costs is a key driver of design decision-making ( Davis et al. 2011). Barriers between work and personal life are breaking down as people seek career opportunities rather than jobs, work at all hours, make a social life at work, and sleep and eat at work if necessary (López, 2001). What may now be called workspace is diversifying. Mobile work and non-territorial workspace is increasing, and companies are applying quality as well as cost criteria to workspace design (Becker and Kelley, 2004).

As part of these changes, conceptualization of the environments for work is shifting from the notion of workspace as a backdrop, - that is, passive setting-for work, to the concept of workspace as an active support and tool for getting work done (Newsham, 1997). One of the results of this shift is the growing interest in how occupants behave as a function of workspace features (Preiser and Vischer, 2005). Preiser and Vischer (2005) posited that "the workspace must be constructed with the following in mind: Physical comfort which is, the basic human needs such as safety, hygiene and accessibility, which must be assured-usually through applying existing building codes and standards so that users find their environment habitable. Functional comfort, as mentioned previously, refers to the degree to which their environment supports users' tasks. At a more abstract level but equally important to users at work is psychological comfort, including feelings of belonging, ownership and control over the Workspace."

How workspace is designed and occupied affects not only how people feel, but also their work performance, their commitment to their employer, and the creation of new knowledge (human capital) in the organization and their response to danger (Stegmeier, 2008). These are the cornerstones of the domain known as the environmental psychology of workspace (Stegmeier, 2008).

There are varied types of workplace arrangement; each is defined by their architectural and functional characteristics as articulated by Duffy et al. (2003) thus "cell office (private room); shared room (2-3 people/room); flexible office (no workplace of one's own); combination office (team based office type) and open plan office, broken down into, a. small open plan office (4-9 people /room), b. open plan office of medium size (10-24 people/room) and c. large open plan office (24 people/room)."

Each of these arrangements has its merits and demerits, and the adoption of one or a few to the exclusion of others is a function of many factors such as the nature of business, the level of interaction between the staff, health and safety concerns of the workforce and the work flow ( Aswathappa, 2005). This made Vischer to observe that the range of workspace type is proliferating- open plan, team space, moveable furniture, personal labour or personal environment module or 'gruppenraum '(group office). Workspaces in most offices today combine more than one type of office space and are in state of constant change (Vischer 2006).

\section{The Effect of Unsafe and Unhealthy Environment}

Unsafe and unhealthy environment occur as a result of error (inadvertent act), omission (failure to take precaution which is known to reduce the likelihood of critical incident or situation occurring) and violation (deliberate act which is unsafe) (Makin, 2009). The work place environment in majority of industry is unsafe and unhealthy (Koehn and Datta, 2003) because of bad workplace layout, design and planning. This situation is more acute in the Nigerian environment which is bedeviled by chronic un-employment, corruption, bad and out dated legislation and inappropriate enforcement mechanism. The shortcomings highlighted above manifest itself in poorly designed workstations unsuitable furniture, lack of ventilation, inappropriate lighting, excessive noise, insufficient safety measures in fire emergencies and lack of 
personal protective equipment. People working in such environment are prone to occupational diseases that impacts on employee's performance (Chandrasekar, 2011) and their productivity continue to decrease at an alarming rate (Hagberg et al. 2002). The quality of the employee's workplace environment must impact on their health and level of motivation (Bakker and Demerouti, 2007). The comfort of workforce with regard to the physical environment, especially the immediate environment, influences to a great extent their error rate, level of innovation and collaboration with other employees, absenteeism and ultimately, how long they stay in the job (MacLeod and Clarke, 2011). The relationship between workplace layout and the physical environment need to conducive in order for workers to perform effectively and efficiently. (Leblebici, 2012). The management that works earnestly at improving the physical infrastructure and the workplace layout, is likely to get positive results in improved health of the workers, good relationship with the neighbours, improved morale of the staff, improved productivity and high profit (Kemp JM and Baker K, 2007).

\section{Conclusion}

The physical workplace environment is very important. It affects the health and safety of the workforce in no small measure, either positively or negatively. The physical work environment is not of much value in Nigeria. This is because of the prevalent unemployment, the value attached to life, widespread corruption, the disdain of the ruling class and the labour aristocrats to the plight of the workforce which led to a very weak, outdated and lax health and safety laws and regulations. This is further compounded by bad planning laws and low monetary compensation paid for infringement of even the lax laws. There is the need to strengthen the law, with the aim of removing the hazards for instance, by changing the process, or by using safer chemicals; changing the work policies and procedure for instance by adequate and detailed planning, working in teams, mentoring; and using personal protective equipment such as hardhat, goggles, gloves and respirators. Furthermore, good arrangement of the workplace apart from aiding performance reduces accidents and aid evacuation in cases of accidents.

\section{References}

AHC 2009. Alberta Health Services Strategic Direction. From http://www.albertahealthservices.ca/org/ahs-org-strategic-direction.pdf. (Retrieved on 24 July, 2012).

Anzi NM 2009. Workplace Environment and its impact on employees' performance. Open University Of Malaysia.

Aswathappa K 2005. Human resource and personnel management. Tata McGraw-Hill Publishing, California, USA.

Bakker AB, Demerouti E 2007. The job demands-resources model: State of the art. Journal of managerial psychology, 22(3): 309-328.

Becker, F., \& Kelley, T. (2004). Offices at Work: Uncommon Workspace Strategies that add Value and Improve Performance. Oxford, England: Elsevier.

C Henderson, R Tunks - POLICY, 2013. From http://www.slater.leicester.sch.uk/uploads/files/policy_documents/. (Retrieved on 24 July, 2014).

Carayon p, A Schoofs Hundt, B-T Karsh, A P Gurses, C J Alvarado, M Smith, P Flatley Brennan 2006. Work system design for patient safety: the SEIPS model. Quality Safety Health Care, 15:150-158.

Chandrasekar k 2011. Workplace environment and its impact on organisational performance in public sector organisations. International Journal of Enterprise Computing and Business Systems. From http://www.ijecbs.com, (Retrieved on 9 January, 2012).

Coker A, Abimbola Sangodoyin, Mynepalli Sridhar. Colin Booth, Paul Olomolaiye, Felix Hammond 2009. Medical waste management in Ibadan, Nigeria: Obstacles and prospects. Waste Management, 29(2): 804-815.

Courtney TK, Gary S. Sorock, Derek P. Manning, James W. Collins \& Mary Ann Holbein-Jenny 2001. Occupational slip, trip, and fallrelated injuries - can the contribution of slipperiness be isolated? Ergonomics, 44(13): 1118-1137.

Davis MC, DJ Leach, CW Clegg 2011. The Physical Environment of the Office: Contemporary and Emerging Issues. From http://lubswww.leeds.ac.uk/fileadmin/webfiles/cstsd/Documents/The_Physical_Environment. (Retrieved on 29 October, 2013).

Duffy F 1997. The New Office. London: Conran Octopus; Jacqueline C. Vischer (2008) Towards an Environmental Psychology of Workspace: How People are affected by Environments for Work. Architectural Science Review, 51(2): 97-108.

Duffy VG, Flora F. Wu, Parry P.W. Ng 2003. Development of an Internet virtual layout system for improving workplace safety. Computers in Industry. 50(2):2072):e.

Fisher L 2003. Shaping the Millennium: A History of Child and Home Injury Prevention with Applications to Leadership Systems. From http://www.apha.org/NR/rdonlyres/596F99CB-1762-4AD2-994D-

47EEE812325F/0/FisherHistriography080912WithPermissionsWileyandSons.pdf. (Retrieved on January 16, 2012).

Freeman RE 2010. Strategic management: A stakeholder approach. Cambridge University Press, Cambridge, USA.

Hagberg M, Tornqvist EW, Toomingas A 2002. Self-Reported Reduced Productivity Due to Musculoskeletal Symptoms: Associations with Workplace and Individual Factors Among White-Collar Computer Users. Journal of Occupational Rehabilitation, 12(3): 151162. 
Hughes P and Ferrett E 2005. Introduction to Health and Safety in Construction. Elsevier Butterworth, Heinemann Paris.

Hughes P, Ferrett E 2011. Introduction to Health and Safety in Construction: The Handbook for Construction Professionals and Students on NEBOSH and Other Construction Courses. Routledge, New York, UK.

Jacqueline C 2008. Towards an Environmental Psychology of Workspace: How People are Affected by Environments for Work. Architectural Science Review, 51(2): 97-108.

JM Kemp, K Baker - 2007. Building Community in Buildings: The Design and Culture of Dynamic Workplaces. From http://scholar.google. co.za/scholar?hl=produ\&btnG=\&as_sdt=1\%2C5\&as_sdtp= - (Retrieved on 16 March, 2013).)

Koehn EE, Datta NK 2003. Quality, environmental, and health and safety management systems for construction engineering. Journal of Construction Engineering and Management. 129(5): 562-569.

Leblebici D 2012. Impact Of Workplace Quality On Employee's Productivity: Case Study Of A Bank In Turkey. Journal of Business Economics, 1(1):38-49.

López GR 2001. The value of hard work: Lessons on parent involvement from an (im) migrant household. Harvard Educational Review, 71(3): 416-438.

Lundgren RE, McMakin AH 2013. Risk communication: A handbook for communicating environmental, safety, and health risks. John Wiley \& Sons, New Jersey, USA.

MacLeod D, Clarke N 2011. Engaging for success: enhancing performance through employee engagement, a report to Government. From http://dera.ioe.ac.uk/1810/1/file52215.pdf. (Retrieved on 21 February, 2013).

Makin AM 2009. Applying the "safe place, safe person, safe systems" framework to improve OHS management: a new integrated approach. From unsworks.unsw.edu.au. http://unsworks.unsw.edu.au/fapi/datastream/unsworks:5001/source02. (Retrieved on 12 January, 2013).

Mehtar S 2010. Understanding infection prevention and control. Juta and Company Ltd, Cape Town, South Africa.

Mensah LD, Julien D 2011. Implementation of food safety management systems in the UK. Food Control, 22(8):1216(8):t.

Newsham, G 1997. Cost-effective open plan environments (COPE): A new research initiative. Construction Innovation, 3(1): 32-34.

Oluwole A 1991. Regulation of Occupational Safety, Health and Environment in Nigeria. Occasional Paper Nigerian Institute of Advanced Legal Studies. Lagos

Orna E 2005. Making knowledge visible: communicating knowledge through information products. Gower Publishing, London, UK.

Preiser E and Vischer C (2005). Assessing Building Performance. Oxford, England: Elsevier.

Price I 2002. The Complex Adaptive Workplace: A theoretical link between office design and productivity? From http://www.fmkx.co.uk/ download/files/FM_Library_reports/Cambridge_2003.pdf. (Retrieved on 22 June, 2013).

Rafiq M. Choudhry, Dongping Fang, Sherif Mohamed 2007. The nature of safety culture: A survey of the state-of-the-art. Safety Science, 45(10): 993-1006.

Rogers MD 2003. Risk analysis under uncertainty, the Precautionary Principle, and the new EU chemicals strategy. Regulatory Toxicology and Pharmacology. 37(3): 370-385.

Rothwell WJ, JM Stavros, RL Sullivan, A Sullivan 2009. What are organization development (OD) and change management (CM)? John Wiley \& Sons, California, USA.

Stefan S 2006. Emergency Department Treatment of the Psychiatric Patient: Policy Issues and Legal Requirements: Policy Issues and Legal Requirements. Oxford University Press, Oxford, UK.

Stegmeier D 2008. Innovations in office design: The critical influence approach to effective work environments. John Wiley \& Sons, New Jersey, USA.

Vischer J 2006. The concept of workspace performance and its value to Managers. University of California Berkeley.

Wilson MG, David M. Dejoy, Robert J. Vandenberg, Hettie A. Richardson, Allison L. Mcgrath 2004. Work characteristics and employee health and well-being: Test of a model of healthy work organization. Journal of Occupational and Organizational Psychology. 77(4): 565-588.

Woolfson C 2005. Health and safety at work after enlargement: a new European strategy or more of the same? Policy and Practice in Health and Safety, 1(3): 21-40. 